Genij Ortopedii. 2021. Vol. 27, no. 6. P. 732-739.

Original article

https://doi.org/10.18019/1028-4427-2021-27-6-732-739

\title{
Probability analysis of peri-implant infection following external transpedicular spine fixation
}

\section{Olga V. Berdiugina}

Institute of Immunology and Physiology of the Ural Branch of the Russian Academy of Sciences, Ekaterinburg, Russian Federation, berolga73@rambler.ru

\begin{abstract}
The main purpose of spinal fixation is to provide conditions for vertebral fusion at the level of injury. Bone fusion is associated with many factors including stability of injured segment, restoration of the anterior support column, condition of the bone tissue and other aspects. The timing of bone formation can be affected by soft tissue inflammation at the site of the rods of the external fixation system. Peri-implant infection is reported to occur in $0.7-20 \%$ of cases with external transpedicular fixation. The timing of the complication and the dependence of the frequency of the occurrence on the patient's treatment strategy are debatable. Another topical issue is the study of the consequences of peri-implant infection with the need to establish the validity of the assumption about the effect of peri-implant infection on the rate of bone formation using a clinical model. This would allow the findings to be used for new methods of treatment considering the risk of possible complications, giving preference to low-traumatic semi-closed methods of spine fixation. Nevertheless, external transpedicular fixation is practical for open spinal injury or significant vertebral displacement with the need of significant reduction efforts to be applied. The purpose was to explore the effect of soft tissue inflammation on the timing of bone formation with spinal fusion surgery using different surgical methods of treatment of uncomplicated spinal fractures. Material and methods The review included 111 patients with uncomplicated fractures of the lower thoracic and lumbar spine. Based on a retrospective analysis the participants were assigned to three groups depending on the presence/absence of peri-implant infection and the timing of the occurrence: 81 patients experienced no complications, 16 had serous-purulent inflammation of soft tissues at the site of the rods of the external fixation device that developed on average after 20 days with 14 patients seen with pin tract infection after 2 months of anterior fusion surgery and failed bone formation. Results Peri-implant infection rate was found to be higher with external fixation (14.4 \%) than that with anterior fusion surgery (12.6\%). The complication rate was 1.85 times less with one-stage surgical treatment as compared to two-stage treatment. Peri-implant infection developed later (after 21-63 days) with one-stage treatment as compared with two-stage procedure (after 12-24 days). Infection associated with the external fixation led to increase in timing of bone formation by 6-7 \%, by $2-4$ weeks on average. Bone formation failed in $35 \%$ of cases $(p<0.0002)$ due to peri-implant inflammation caused by Staphylococcus aureus, as the common pathogen and the bacteria detected resulted in ineffective antibacterial therapy. Immunological parameters (IgM and haptoglobin) were quantified to assess the risk of peri-implant infection. Discussion Peri-implant infection rate associated with external transpedicular fixation was shown to be comparable with the previously obtained data. Sharply defined notions were reported earlier to differentiate between infectious peri-implant osteolysis and mechanical loosening. We compared the data on the duration of bone formation and the timing of peri-implant infection and developed a model that with high sensitivity (73 \%) and specificity (100 \%) allowed description of cases with impaired osteogenesis. Changes in some immunological parameters (immunoglobulins, acute-phase proteins) were shown to affect both bone formation and stability of bone fixation.
\end{abstract}

Keywords: bone fixation, spine, bone formation, complication, infection

For citation: Berdiugina O.V. Probability analysis of peri-implant infection following external transpedicular spine fixation. Genij Ortopedii, 2021, vol. 27, no 6, pp. 732-739. https://doi.org/10.18019/1028-4427-2021-27-6-732-739.

\section{INTRODUCTION}

External transpedicular osteosynthesis has been used to treat spinal injuries and diseases [1-7]. A retrospective analysis of the data based on the results of patient's monitoring in the postoperative period allows evaluation of the effectiveness of surgical intervention to develop safe and effective methods for spinal injuries and diseases. The main purpose of spinal column fixation is to create conditions for the spinal fusion at the level of injury and eliminate all components of bone displacement. Bone fusion depends on many factors including the stability of bone segments, the restoration of the anterior and posterior support columns, bone density, length and type of stabilizing construct and other aspects [8-13]. There is evidence that the timing of the formation of spondylodesis may be affected by inflammation of soft tissues at the rods of the external fixation device [14]. Infection can be caused by unstable fixation of the metal construct leading to impaired osteogenesis, allergic reactions to the components of the device, activation of immune reactions, cytokine production or increased expression of nuclear factor-kB, in particular [14].

Peri-implant infection is reported to occur in $0.7-20 \%$ of cases with external transpedicular fixation [15]. The timing of the complication and the correlation between the frequency of occurrence and the patient's treatment strategy are debatable. Spinal deformity correction can be produced using various approaches at one or two stages [16], and the option remains controversial [17-19]. Two-stage surgical treatment allows stabilization of spinal injury and reduction of complications. Unstable fractures only can be an indication for this approach [20,21]. Although one-stage treatment can be equally safe and effective

(c) Berdyugina O.V., 2021 
as two-stage treatment some patients can develop long-standing pain [22-24]. The advantages of each of the treatment options can be determined by long-term treatment results $[25,26]$. Peri-implant infection can affect fusion [14]. It becomes important to establish the validity of this assumption on a clinical model. Another topical issue is the study of the consequences of peri-implant infection with the need to establish the validity of the assumption about the effect of periimplant infection on the rate of bone formation using a clinical model.

Analysis of complications of surgical treatment of spinal injuries using different constructs is aimed at finding new ways of patient's recovery considering the mechanisms of osteogenesis, improving clinical results of treatment and reducing the identified risks based on retrospective studies. The purpose was to explore the effect of soft tissue inflammation on the timing of bone formation with spinal fusion surgery using external fixation device at one- and two-stage treatment of uncomplicated spinal fractures.

\section{MATERIAL AND METHODS}

The design of the clinical trial is a retrospective monocenter cohort.

The model of spinal injury treatment is based on the use of an external transpedicular fixation system associated with mechanisms of osteogenesis using a device implying the contact of the rods of the apparatus and the skin.

Duration of the study Long-term results of treatment of patients were followed for up to 20 years. The median follow-up period was 201 months (16.8 years).

Ethics of research The study was approved by the ethics committee of the State Medical Institution "Center for Specialized Medical Care "Ural Institute of Traumatology and Orthopedics named after V.D. Chaklin". Documents submitted for ethical approval included an abstract, research protocol, $\mathrm{CV}$ of the researcher, an informed consent form from the patient. The research was carried out in accordance with international documents based on the Helsinki Declaration of the World Medical Association with subsequent amendments [27], the guidelines for good clinical practice, the Russian "Code of Medical Ethics", documents of the United Nations and the Council of Europe concerning the rights of the patient. The subjects were informed about the risks and benefits of participating in the study in accessible terms.

The review included 111 patients with uncomplicated fractures of the lower thoracic and lumbar spine. The injuries were located at the levels: $\operatorname{Th} 7(\mathrm{n}=3)$; Th8 (n=4); Th9 $(\mathrm{n}=2)$; Th10 $(\mathrm{n}=5)$; Th11 $(\mathrm{n}=6)$; Th12 (n= 20); L1 ( $\mathrm{n}=40) ;$ L2 (n=19); L3 ( $=7)$;

L4 $(n=3)$; L5 $(n=2)$. The distribution of vertebral fractures by AO is presented in Table 1.

Comprehensive clinical and instrumental examination was performed for the patients on admission and postoperatively according to the standards of specialized medical care.

Instrumental studies were performed in the diagnostic imaging department and included AP and lateral radiographs of the spinal injury to determine ratio of the heights of injured and intact discs, assess wedge-shaped deformity and other parameters. Linear tomograms of the fractured bone and adjacent segments demonstrated location and size of the injury, pedicles of the vertebral arches to place transpedicular screws. Magnetic resonance imaging was used to evaluate intervertebral discs and ligaments, presence and extent of vertebro-medullary conflict.

Inclusion criteria were age of 18 to 65 years and uncomplicated injuries of the thoracic and lumbar spine confirmed by instrumental studies [28].

The exclusion criteria were combined musculoskeletal injuries, complicated spinal injuries, including spinal trauma (type $\mathrm{C}$ lesions (anterior and posterior injuries at rotation)) may not always be accompanied by neurological deficits), cognitive disorders, degenerative bone lesions, immunedependent diseases, osteoporosis, concomitant diseases in the acute stage; detection of HBs antigen, antibodies to human immunodeficiency virus and hepatitis $\mathrm{C}$, participation in other clinical trials and refusal of the patient from participation in the study.

Table 1

Distribution of uncomplicated vertebral fractures according to AO classification [28]

\begin{tabular}{|c|c|c|c|c|c|}
\hline \multicolumn{2}{|c|}{ Type A injury } & \multicolumn{2}{|c|}{ Type B injury } & \multicolumn{2}{|c|}{ Type $\mathrm{C}$ injury } \\
\hline Type & Number of patients & Type & Number of patients & Type & Number of patients \\
\hline A.1.1 & 5 & B.1.2.1. & 2 & C.1.3. & 2 \\
\hline A.1.2.1. & 13 & B.2.1. & - & C.2.1.7. & 1 \\
\hline A.1.2.3. & 2 & B.2.3 & 2 & C.3.1. & 3 \\
\hline A.2.1.1. & 2 & B.2.3.1. & 43 & - & - \\
\hline A.2.3.1. & 6 & B.2.3.2. & 2 & - & - \\
\hline A.2.1. & 3 & B.3.3. & 1 & - & - \\
\hline A.2.3. & 10 & B.3.2. & 2 & - & - \\
\hline A.3.2. & 2 & - & - & - & - \\
\hline A.3.3.1. & 10 & - & - & - & - \\
\hline
\end{tabular}


Surgical technique Two-stage surgical treatment of patients with uncomplicated fractures of the lower thoracic and lumbar spine included the first stage of spinal osteosynthesis with an external fixation device consisting of 8 threaded rods and two plates connected by rods, and interbody fusion with an autograft harvested from the iliac wing was performed at the second stage. One-stage surgical treatment of spinal injuries included correction of wedge-shaped vertebral deformity and kyphosis in the vertebral motion segment due to ligamentotaxis; fractures type $\mathrm{A}$ in the absence of indications for reconstructive intervention for the anterior and middle columns of the spine. Dorsal fusion was not produced at one-stage correction with ExFix. Indications to the second stage of interbody fusion of injured motion vertebral segments included destruction of the vertebral body with injury to adjacent intervertebral discs; the absence of distraction regenerate with long-standing injuries; preservation of the achieved spinal correction in neglected cases with the deformity corrected with vertebral transposition. The operations were performed under endotracheal anesthesia

Postoperative care Patients were encouraged to ambulate after 2-3 postoperative days of the first surgery and after 5-7 days of the second procedure. All subjects received standard therapy. The principle of forming groups: patients were grouped retrospectively based on the clinical diagnosis established by physical examination, instrumental and laboratory tests without significant differences in sex and age.
Differentiation of groups All participants were differentiated into three groups depending on the presence / absence of complications of surgical treatment: periimplant infection and timing of the occurence after external fixation / after anterior fusion (Table 2). Patients were differentiated without reference to the type of injury because the severity of A3 type may be greater than that in B1 injury.

Early and late postoperative periods were uneventful in group I $(\mathrm{n}=81,73 \%)$ with bone consolidation developed within 4 to 6 months with uncomplicated osteogenesis. 16 (14.4\%) patients (group II) developed pin tract infection with external fixation device that occurred after $19.0 \pm 3.0$ postoperative days (from 13 to 63), hereinafter referred to as "after 20 days" of vertebral osteosynthesis with an external fixation device. Smoldering chronic serous or purulent inflammation could not be resolved by a course of antibiotic therapy and daily dressings and metal rods were removed to avoid osteomyelitis.

The third group consisted of 14 (12.6\%) patients who developed pin tract infection with external fixation device after $58.2 \pm 5.7$ days (from 21 to 63 ), hereinafter referred to as " 2 months" after anterior fusion. The rods were removed or the device was dismantled [29-30] to avoid osteomyelitis and bone fusion of tissue did not occur in due time (4-5.5 months) and furtheron after (up to 7 months of observation). The treatment failed and this group of patients was represented by patients who had only two-stage treatment.

Table 2

Distribution of patients in study groups

\begin{tabular}{|c|c|c|c|c|c|}
\hline & \multicolumn{2}{|c|}{$\begin{array}{l}\text { Group I. Patients with uneventful } \\
\text { treatment }(\mathrm{n}=81)\end{array}$} & \multicolumn{2}{|c|}{$\begin{array}{c}\text { Group II. Pin tract infection developed } \\
\text { average after } 20 \text { days of external } \\
\text { fixation }(\mathrm{n}=16)\end{array}$} & \multirow{2}{*}{$\begin{array}{c}\text { Group III. Pin tract infection } \\
\text { developed average after } \\
2 \text { months of anterior fusion } \\
\text { fixation }(\mathrm{n}=14)\end{array}$} \\
\hline & Subgroup 1 & Subgroup 2 & Subgroup 1 & Subgroup 2 & \\
\hline & One-stage treatment & Two-stage treatment & One-stage treatment & Two-stage treatment & Two-stage treatment \\
\hline $\begin{array}{l}\text { Number of patients } \\
\text { (\% in the group) }\end{array}$ & $29(35.8)$ & $52(64.2)$ & $6(37.5)$ & $10(62.5)$ & $14(100.0)$ \\
\hline $\begin{array}{l}\text { Distribution by sex - } \\
\text { number of patients } \\
\text { (\% in the group) }\end{array}$ & $\begin{array}{l}\mathrm{M}-18(62.1) \\
\mathrm{F}-11(37.9)\end{array}$ & $\begin{array}{c}M-33(63.5) \\
F-19(36.5)\end{array}$ & $\begin{array}{l}M-5(83.3) \\
F-1(16.79)\end{array}$ & $\begin{array}{l}M-7(70.0) \\
F-3(30.0)\end{array}$ & $\begin{array}{l}M-7(50.0) \\
F-7(50.0)\end{array}$ \\
\hline Age, years & $25(21-35)^{*}$ & $29(23-39)^{*}$ & $41(31-46)^{*}$ & $35(28-48)^{*}$ & $28(23-39)^{*}$ \\
\hline $\begin{array}{l}\text { When did injury occur, } \\
\text { days ago }\end{array}$ & $21(10-45)^{*}$ & $36(18-96)^{*}$ & $19(8-38)^{*}$ & $17(13-17)^{*}$ & $27(10-44)^{*}$ \\
\hline $\begin{array}{l}\text { Comorbidity, } \\
\text { individuals (\%) }\end{array}$ & $12(41.4)$ & $37(71.1)$ & $3(50.0)$ & $7(70.0)$ & $8(57.1)$ \\
\hline $\begin{array}{l}\text { Interval between } \\
\text { treatment stages, days }\end{array}$ & 0 & $31(19-41)^{*}$ & 0 & $39(33-43)^{*}$ & $28(14-41)^{*}$ \\
\hline $\begin{array}{l}\text { Formation of bone } \\
\text { fusion, months }\end{array}$ & $5(4-6)^{*}$ & $5.3(4-5)^{*}$ & $4.5(4-7.3)^{*}$ & $5.7(5-6.3)^{*}$ & $4.9(3.5-5.5)^{*}$ \\
\hline Blood loss, L & $0(0.00-0.03)^{* * * *}$ & $0.4(0.30-0.80)^{*, * *}$ & $0(0.00-0.04)^{*, * *}$ & $\begin{array}{l}0.58(0.43- \\
1.04)^{*, * *}\end{array}$ & $0.43(0.26-0.58)^{*, * *}$ \\
\hline $\begin{array}{l}\text { Timing of occurrence } \\
\text { of complications from } \\
\text { the last surgery, days }\end{array}$ & 0 & 0 & $42(21-63)^{*}$ & $16(13-24)^{*}$ & $55(14-62)^{*}$ \\
\hline
\end{tabular}

Note: $\mathrm{M}$ - male; $\mathrm{F}$ - female ; ${ }^{*}$ - median and interquartile range; ${ }^{* *}$ - blood loss for one or total for two operations. 
Assessment of the bone fusion Radiography and $\mathrm{CT}$ scans were used monthly to assess bone fusion at the level of injured vertebral motion segment due to ossification of the anterior longitudinal ligament in the group of one-stage surgical treatment and at the level of fusion using autograft in the group of two-stage surgical treatment starting from the second month after surgery until the appearance of radiological signs of fusion. A fracture line, bone resorption at the fracture level and fusion within a period of more than 6 months postsurgery were criteria for incomplete fusion.

Additional investigations Clinical, biochemical and immunological parameters of peripheral blood were used to identify risks of complications in all patients. The Cell Dyn 1700 (Abbott, USA) and Ciba Corning Express Plus (Diagnostics, Germany) analyzers and reagents were used. Microorganisms for nonspecific spondylitis and the sensitivity to antibacterial drugs were identified using semi-automatic bacteriological analyzers Vitek 2-compact and ATB-Expression (Biomerieux, France) and reagents of the same companies according to standard methods.
Statistical data processing Statistical processing was produced with exploratory analysis and basic statistics using "Microsoft Office Excel 2007" (Microsoft Corp., USA) and "Statistica for Windows v.6.1." (StatSoft., USA). A comparative evaluation of the frequency of the variables was performed using the Pearson's chi-squared test. The distribution of variables in the groups was abnormal, the independent samples were small and nonparametric criteria were used to assess the differences between the cohorts, number of inversions (Mann-Whitney U-test) [31-32] after making sure that the data did not contain matching values [33]. The differences between the samples were considered statistically significant at $p \leq 0.05$. Linear regression and correlation analyses were performed to assess the relationship between the duration of bone fusion and the presence of peri-implant infection. Data visualization and ROC analysis with measuring the area under the curve (area under the ROC curve, AUC) was produced with the Graph Pad Prism 8.0.2.263 application (Software, Inc.).

\section{RESULTS}

The results of treatment were evaluated in three groups of patients: 81 patients who developed no complications (group I), 16 patients with periimplant infection that occurred average 20 days after external fixation (group II), and 14 patients who developed pin tract infection with the external fixation apparatus average 2 months after anterior fusion (group III) and led to incomplete bone consolidation. The rate of periimplant infection that occurred after external fixation was slightly higher than that after anterior fusion, and was $14.4 \%$ (group II) and $12.6 \%$ (group III), respectively (Fig. 1). There were significant differences in the values $\left(\chi^{2}=43.7, p<0.05\right)$.

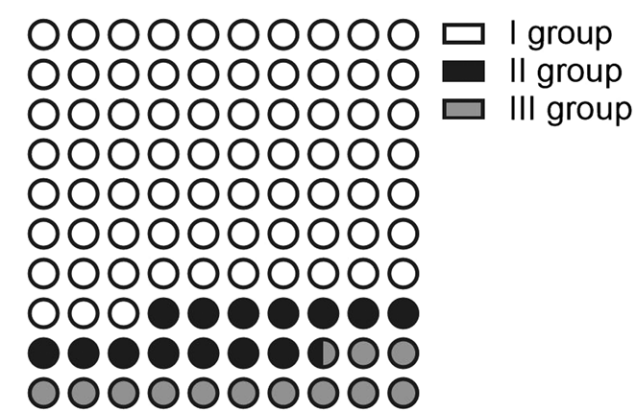

Fig. 1 The ratio of cases of peri-implant infection after external fixation (group II) and anterior fusion (group III) in comparison with patients with uncomplicated course of bone fusion (group I)

Correlation between the occurrence of complications and the type of treatment strategy used was another important aspect of the study. Infection cases were 1.85 times less with one-stage surgical treatment than that with two-stage treatment (Fig. 2) with the differences being also significant $\left(\chi^{2}=28.6, \mathrm{p}<0.05\right)$.

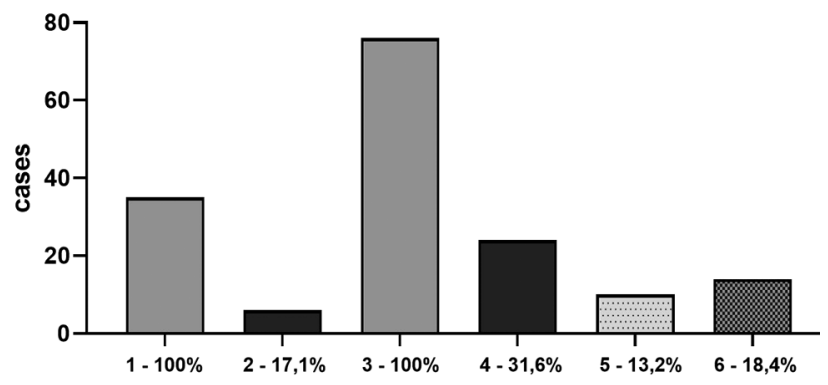

Fig. 2 The rate of periimplant infection with one-stage surgical treatment (2) in comparison with the total number of such operations (1); the rate of pin tract infection with two-stage surgical treatment (4) in comparison with the total number of such operations (3), from them: after fixation with the frame (5), after anterior fusion (6)

The timing of infection occurrence was the third important aspect of the study. Group III group was homogeneous, and additional investigation was performed for group II including patients who underwent one-stage and two-stage surgical treatment. Although complications were observed 20 days after external fixation the results obtained differentially for subgroups with different treatment strategies showed that infection with one-stage treatment occurred later (2.6 times, U-test, $\mathrm{p}<0.05$ ), after $21-63$ days from the beginning of the treatment as compared with two stages when complications were recorded after 12-24 days of observation (Fig. 3).

The timing of bone fusion was explored depending on the presence or absence of peri-implant infection. Infection developed after osteosynthesis with an external fixation device led to increase in length of the bone fusion by $6-7 \%$, that is, average by $2-4$ weeks. With pin tract infection after anterior fusion (group III), 
bone fusion failed with the external fixation device dismantled after average of $3.75 \pm 0.31$ months (Fig. 4, (5)) to avoid chronic serous or purulent inflammation that failed to be resolved with a course of antibiotic therapy and daily dressings. Two-stage treatment with uneventful postoperative period led to greater timing of bone fusion by $5 \%$, or $6-8$ days, and the difference was significant (U-test, $\mathrm{p}<0.001$ ), Figure 4. A more significant difference in the timing of bone fusion between one-stage and two-stage treatment was observed with peri-implant infection after application of the device. Bone fusion with the two-stage treatment increased by $26.7 \%$, or average of 36 days (U-test, $\mathrm{p}<0.001$ ), Figure 4.

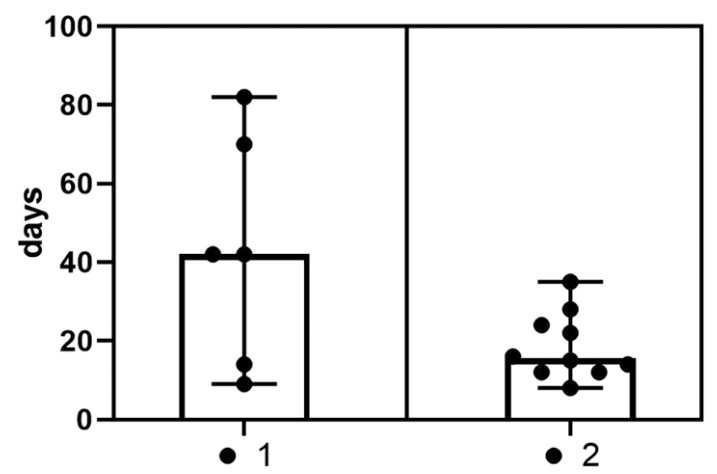

Fig. 3 The timing of the occurrence of peri-implant infection after external fixation with one-stage (1) and two-stage (2) surgical treatment

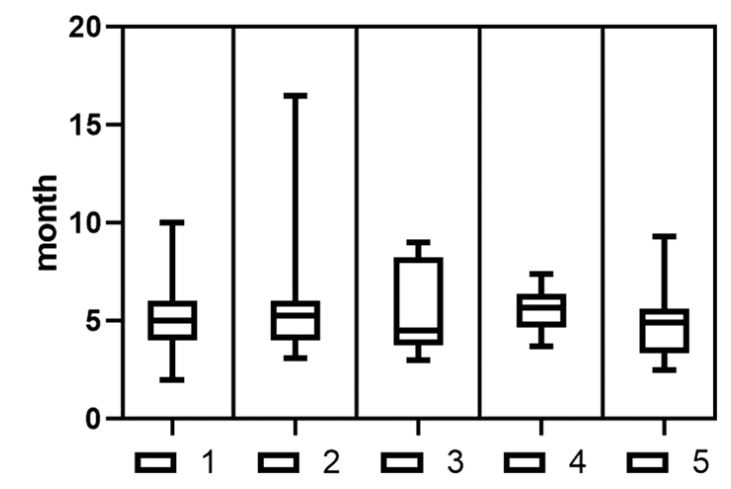

Fig. 4 The timing of bone fusion in patients without complications with one-stage treatment (1), with two-stage treatment (2), in patients with peri-implant infection after fixation with the frame: with one-stage (3) and two-stage (4) surgical treatment, in patients with pin tract infection after anterior fusion, the length of the external fixation indicated with fusion failure (5)

Linear regression and correlation analysis was performed to assess the relationship between the duration of bone fusion and peri-implant infection. The use of these methods allowed description of $35 \%$ of the cases $(\mathrm{p}<0.0002)$. ROC analysis was used to explore the relationship between the duration of bone fusion and the time of occurrence of peri-implant infection with high sensitivity $(73 \%)$ and specificity $(100 \%)$ : $\mathrm{AUC}=0.751$ (standard error 0.04, $\mathrm{p}<0.0001$ ). The correlation between the duration of bone fusion formation and the number of treatment stages was also established with $\mathrm{AUC}=0.997$, standard error 0.004, $\mathrm{p}<0.0001$, sensitivity of $100 \%$, specificity of $99.1 \%$. Analysis of the pathogens for peri-implant infection showed that Staphylococcus aureus was detected in $92 \%$ of cases in group II, and staphylococcus was detected in $95 \%$ of cases in group III with no significant differences. Other pathogens of less than $1 \%$ were Pseudomonas aerugenosae, Burkholderia cepacia, Actinetobacter baumanii, Enterococcus faecalis, Proteus vulgaris.

Major (general clinical, biochemical) and additional (immunological) laboratory parameters were measured to monitor possible complications. Preoperative leukocyte counts and the subpopulations, parameters for assessing fat, carbohydrate and protein metabolism, electrolyte levels and acid state in groups I, II and III showed no significant differences, for example, leukocyte counts (Fig. 5, L (I), L (II), L (III)). The IgM concentration (Fig. 5, IgM (I), IgM (II), IgM (III)) and the haptoglobin level (Fig. 5, Hp (I), Hp (II), Hp (III)) significantly differed among the groups.

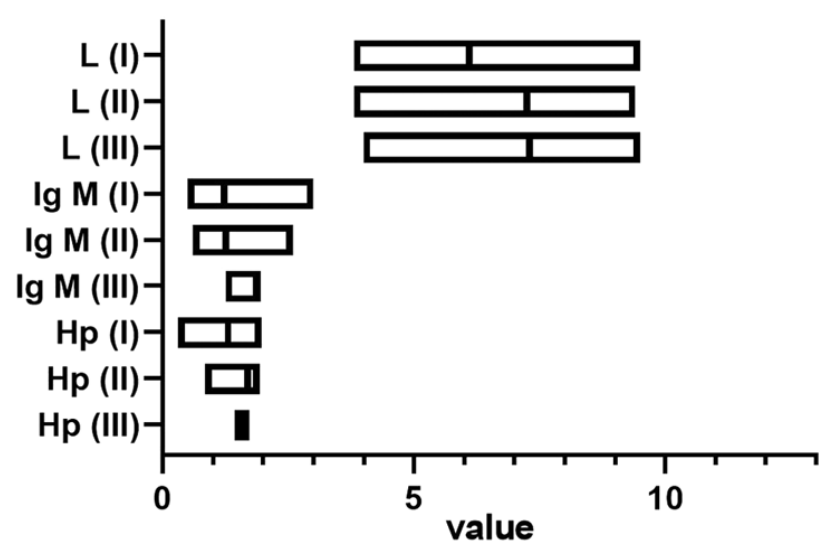

Fig. 5 Several preoperative laboratory parameters measured preoperatively showing significant differences in groups I, II and III: (IgM (I), g/l, IgM (II), g/l, IgM (III)*, g/l and Hp (I), g/1, Hp (II)*, g/1, Hp (III)* g/l), where * is U-test, $\mathrm{p}<0.001$ showing no significant differences: L (I), $\times 10^{9} / 1$, L (II),$\times 10^{9} / 1$, L (III) $\left.\times 10^{9} / 1\right)$

\section{DISCUSSION}

The result of the retrospective analysis is the search for ways to correct existing treatment methods, reduce the complication rate and improve treatment outcomes. The model for the study was the system of external transpedicular fixation used for treatment of uncomplicated spinal fractures considering well explored mechanisms of osteogenesis and the presence of contact between rods of the apparatus and the skin. Although the method provides effective and longterm repair of injuries [34], the use of transpedicular fixation of the spine allows bone fusion at the level of the affected segment for 4-6 months [35], some 
problems are to be addressed [36]. Most common complications include failure of fusion, neurological disorders, impaired bone stabilization and resorption leading to a decreased strength of fixation of transpedicular rods $[37,38]$, postoperative wound infection and pin tract infection [39]. It is obvious that each of the complications can lead to a poor outcome. The incidence of periimplant infection with external transpedicular osteosynthesis ranges between 12.6 and $14.6 \%$ that is comparable with the previously reported data [15]. According to some authors [14] and with own experience [10] pin tract infection with external transpedicular fixation leads to impaired osteogenesis and increased timing of bone fusion and can result in incomplete fusion in some cases.

There are clear criteria reported to differentiate between infectious peri-implant osteolysis and mechanical loosening. With mechanical loosening of a screw, the osteolysis may be more prominent along the distal tip owing to a pivot point around which the screw moves, whereas infectous osteolysis is often more diffuse on CT scan [40]. We compared duration of bone fusion formation and the timing of peri-implant infection and obtained a model that with high sensitivity (73\%) and specificity (100\%) allowed us to describe up to $35 \%(\mathrm{p}<0.0002)$ of cases with impaired osteogenesis. Other factors of joint stability, bone density, type of stabilizing construct can play an important role in osteogenetic disorders. Peri-implant infection developed in $17.1 \%$ of cases with one-stage surgical treatment and in $31.6 \%$ with two stages (1.9 times greater). The formation of bone fusion was delayed during the two-stage treatment by $26.7 \%$, that is, by more than 1 month. Immune mechanisms are known to play an additional role in slowing down the formation of bone fusion. Initiation of such reactions (for example, through the use of recombinant proteins) can lead to inflammation, and it becomes much more difficult to differentiate the cause of the complication. Such manifestations of osteogenetic disorders on postoperative spinal CT scans can be regarded as an imitation of infection [40]. Immunological studies can help in differential diagnosis with the use of microbiological methods to identify the pathogen. Our study revealed changes in some immunological parameters (immunoglobulins, acute-phase proteins), confirming the fact that the immune system is involved in osteogenesis and the stability of the construct fixation in the bone [41]. Despite the fact that most cases of peri-implant infection are caused by Staphylococcus aureus, microorganisms of the gastrointestinal tract (Enterococci, Proteus and others) can also cause the inflammation [14] that is comparable with our findings. It is important that gram-negative Pseudomonas aeruginosa is associated with a significantly higher rate of ineffective treatment compared to the cases caused by staphylococci [42] that would be interesting to explore in additional studies, since the microorganisms were also detected but were not common. We can suggest that immunological parameters (IgM and haptoglobin) can be used to monitor complications, peri-implant infection, in particular, and the findings can be used to create new methods for uncomplicated spinal fractures.

\section{CONCLUSION}

The rate of peri-implant infection was $14.4 \%$ of cases with external transpedicular osteosynthesis of the spine and $12.6 \%$ with anterior fusion. Pin tract infection with the external fixation device was 1.85 times greater with two-stage treatment strategy and complications developing earlier (after 12-24 days postsurgery) than that with one-stage treatment (after 21-63 days postsurgery). Fusion failed in $35 \%$ of cases $(p<0.0002)$ due to peri-implant infection. Among the pathogens that caused the infection, Staphylococcus aureus was most common and there were bacteria detected that resulted in ineffective antibacterial therapy. Immunological parameters (IgM and haptoglobin) were shown to be practical in assessing the risk of peri-implant infection.

\section{REFERENCES}

1. Danison A.P., Lee D.J., Panchal R.R. Temporary stabilization of unstable spine fractures. Curr. Rev. Musculoskelet. Med., 2017, vol. 10, no. 2, pp. 199-206. DOI: 10.1007/s12178-017-9402-y.

2. Ciurlia E., Caggiari G., Spina M., Andreozzi M., Puddu L., Doria C. A "rising" transpedicular access to anterior vertebral body: A case report. Int. J. Surg. Case Rep., 2017, vol. 38, pp. 13-17. DOI:10.1016/j.ijscr.2017.07.010.

3. Khare S., Sharma V. Surgical outcome of posterior short segment trans-pedicle screw fixation for thoracolumbar fractures. J. Orthop., 2013, vol. 10, no. 4, pp. 162-167. DOI:10.1016/j.jor.2013.09.010.

4. Unterweger M.T., Kandziora F., Schnake K.J. Hybrid Stabilization of Thoracic Spine Fractures with Sublaminar Bands and Transpedicular Screws: Description of a Surgical Alternative and Review of the Literature. Case Rep. Orthop., 2015, vol. 2015, article ID 857607. DOI:10.1155/2015/857607.

5. Heintel T.M., Berglehner A., Meffert R. Accuracy of percutaneous pedicle screws for thoracic and lumbar spine fractures: a prospective trial. Eur. Spine J., 2013, vol. 22, no. 3, pp. 495-502. DOI: 10.1007/s00586-012-2476-8.

6. Ikeuchi H., Ikuta K. Accuracy of pedicle screw insertion in the thoracic and lumbar spine: a comparative study between percutaneous screw insertion and conventional open technique. Arch. Orthop. Trauma Surg., 2016, vol. 136, no. 9, pp. 1195-1202. DOI: 10.1007/ 
s00402-016-2502-0.

7. Dobran M., Nasi D., Brunozzi D., di Somma L., Gladi M., Iacoangeli M., Scerrati M. Treatment of unstable thoracolumbar junction fractures: short-segment pedicle fixation with inclusion of the fracture level versus long-segment instrumentation. Acta Neurochir. (Wien), 2016, vol. 158, no. 10, pp. 1883-1889. DOI: 10.1007/s00701-016-2907-0.

8. Zhao Q., Zhang H., Hao D., Guo H., Wang B., He B. Complications of percutaneous pedicle screw fixation in treating thoracolumbar and lumbar fracture. Medicine (Baltimore), 2018, vol. 97, no. 29, pp. e11560. DOI: 10.1097/MD.0000000000011560.

9. Complications of 2-Level Dynamic Stabilization: A Correlative Clinical and Radiological Ciplak N.M., Suzer T., Senturk S., Yaman O., Sasani M., Oktenoglu T., Yilmaz A., Erbulut D.U., Özer A.F. Analysis at Two-Year Follow-up on 103 Patients. Turk. Neurosurg., 2018, vol. 28, no. 5, pp. 756-762. DOI: 10.5137/1019-5149.JTN.21036-17.1.

10. Berdiugina O.V., Berdiugin K.A., Tsvetkov A.I., Shlykov I.L.; Belokrylov N.M., editor. Immunologicheskii monitoring v prognozirovanii i profilaktike spondilitov $i$ nagnoeniia miagkikh tkanei pozvonochnika [Immunological monitoring in predicting and preventing spondylitis and suppuration of the spine soft tissues]. Ekaterinburg, 2018, 119 p. (in Russian)

11.Bao F.P., Zhang H.G., Zhu S.M. Anesthetic considerations for patients with acute cervical spinal cord injury. Neural Regen. Res., 2017, vol. 12, no. 3, pp. 499-504. DOI: 10.4103/1673-5374.202916.

12.Mizuno T., Sakakibara T., Yoshikawa T., Inaba T., Kato T., Kasai Y. Biomechanical Stability of a Cross-Rod Connection with a Pedicle Screw System. Med. Sci. Monit. Basic Res., 2018, vol. 24, pp. 26-30. DOI: 10.12659/msmbr.906339.

13.Liu Y., Dash A., Krez A., Kim H.J., Cunningham M., Schwab F., Hughes A., Carlson B., Samuel A., Marty E., Moore H., McMahon D.J., Carrino J.A., Bockman R.S., Stein E.M. Low volumetric bone density is a risk factor for early complications after spine fusion surgery. Osteoporos. Int., 2020, vol. 31, no. 4, pp. 647-654. DOI: 10.1007/s00198-019-05245-7.

14.Fang C., Wong T.M., Lau T.W., To K.K., Wong S.S., Leung F. Infection after fracture osteosynthesis - Part I. J. Orthop. Surg. (Hong Kong), 2017, vol. 25, no. 1, 2309499017692712. DOI: 10.1177/2309499017692712.

15.Kochnev E.Ia., Mukhtiaev S.V., Meshcheriagina I.A., Grebeniuk L.A. Klinicheskii sluchai mnogoetapnogo khirurgicheskogo lecheniia patsientki s vertebralnoi implant-assotsiirovannoi infektsiei [Clinical case of multistage surgical treatment of a female patient with vertebral implant-associated infection]. Politravma, 2020, no. 1, pp. 67-73. (in Russian) Available at: https://poly-trauma.ru/index.php/ pt/article/view/203 (accessed 18.06.2020).

16.Su Y., Wang X., Ren D., Liu Y., Liu S., Wang P. A finite element study on posterior short segment fixation combined with unilateral fixation using pedicle screws for stable thoracolumbar fracture. Medicine (Baltimore), 2018, vol. 97, no. 34, e12046. DOI: 10.1097/ MD.0000000000012046.

17.Sebaaly A., Rizkallah M., Riouallon G., Wang Z., Moreau P.E., Bachour F., Maalouf G. Percutaneous fixation of thoracolumbar vertebral fractures. EFORT Open Rev., 2018, vol. 3, no. 11, pp. 604-613. DOI: 10.1302/2058-5241.3.170026.

18.Aly T.A. Short Segment versus Long Segment Pedicle Screws Fixation in Management of Thoracolumbar Burst Fractures: MetaAnalysis. Asian Spine J., 2017, vol. 11, no. 1, pp. 150-160. DOI: 10.4184/asj.2017.11.1.150.

19.Lyu J., Chen K., Tang Z., Chen Y., Li M., Zhang Q. A comparison of three different surgical procedures in the treatment of type A thoracolumbar fractures: a randomized controlled trial. Int. Orthop., 2016, vol. 40, no. 6, pp. 1233-1238. DOI: 10.1007/s00264-0163129-z.

20.Kokushin D.N., Belianchikov S.M., Murashko V.V. Khirurgicheskoe lechenie nestabilnykh povrezhdenii grudnogo i poiasnichnogo otdelov pozvonochnika. Istoricheskie aspekty (obzor literatury) [Surgical treatment of unstable injuries of the thoracic and lumbar spine. Historical aspects (literature review)]. Mezhdunarodnyi Zhurnal Prikladnykh i Fundamentalnykh Issledovanii, 2016, no. 11, part 3, pp. 442-450. (in Russian) Available at: https://applied-research.ru/ru/article/view?id = 10515 (accessed 12.07.2019) .

21.Cao L., Yang E., Xu J., Lian X., Cai B., Liu X., Zhang G. "Direct vision" operation of posterior atlantoaxial transpedicular screw fixation for unstable atlantoaxial fractures: A retrospective study. Medicine (Baltimore), 2017, vol. 96, no. 25, e7054. DOI: 1.1097/ MD.0000000000007054.

22.Viezens L., Reer P., Strahl A., Weiser L., Schroeder M., Beyerlein J., Schaefer C. Safety and Efficacy of Single-Stage versus 2-Stage Spinal Fusion via Posterior Instrumentation and Anterior Thoracoscopy: A Retrospective Matched-Pair Cohort Study with 247 Consecutive Patients. World Neurosurg., 2018, vol. 109, pp. e739-e747. DOI: 10.1016/j.wneu.2017.10.074.

23.Kumar S., Kumar S., Arya R.K., Kumar A. Thoracolumbar Vertebral Injuries with Neurological Deficit Treated with Posterior Decompression, Short Segment Pedicle Screw Fixation, and Interlaminar Fusion. Asian Spine J., 2017, vol. 11, no. 6, pp. 951-958. DOI: 10.4184/asj.2017.11.6.951.

24.Cui S., Busel G.A., Puryear A.S. Temporary Percutaneous Pedicle Screw Stabilization without Fusion of Adolescent Thoracolumbar Spine Fractures. J. Pediatr. Orthop., 2016, vol. 36, no. 7, pp. 701-708. DOI: 10.1097/BPO.0000000000000520.

25.Berdiugin K.A., Berdiugina O.V., Kutepov S.M. Oshibki i oslozhneniia osteosinteza pozvonochnika [Errors and complications of spinal osteosynthesis]. Ekaterinburg, UGMA, 2012, 400 p. (in Russian)

26.Fan Y., Peng D.J., Liu J.J., Zhang J.N., Liu S.C., Hao D.J. Radiological and clinical differences among three assisted technologies in pedicle screw fixation of adult degenerative scoliosis. Sci. Rep., 2018, vol. 8, no. 1, pp. 890. DOI: 10.1038/s41598-017-19054-7.

27.World Medical Association. World Medical Association Declaration of Helsinki: ethical principles for medical research involving human subjects. JAMA, 2013, vol. 310, no. 20, pp. 2191-2194. DOI: 10.1001/jama.2013.281053.

28.Magerl F., Aebi M., Gertzbein S.D., Harms J., Nazarian S. A comprehensive classification of thoracic and lumbar injuries. Eur. Spine J., 1994, vol. 3, no. 4, pp. 184-201. DOI: 10.1007/BF02221591.

29.Ak H., Gulsen I., Atalay T., Gencer M. Does the removal of spinal implants reduce back pain? J. Clin. Med. Res., 2015, vol. 7, no. 6, pp. 460-463. DOI: 10.14740/jocmr2141w.

30.Ho C., Skaggs D.L., Weiss J.M., Tolo V.T. Management of infection after instrumented posterior spine fusion in pediatric scoliosis. Spine (Phila Pa 1976), 2007, vol. 32, no. 24, pp. 2739-2744. DOI: 10.1097/BRS.0b013e31815a5a86.

31.Olsen C.H. Review of the use of statistics in infection and immunity. Infect. Immun., 2003, vol. 71, no. 12, pp. 6689-6692. DOI: 10.1128/IAI.71.12.6689-6692.2003.

32.Wang Y., Hu J., Do K.A., Brian P.H. “An Efficient Nonparametric Estimate for Spatially Correlated Functional Data”, Statistics in Biosciences, Springer. International Chinese Statistical Association, 2019, vol. 11, no. 1, pp. 162-183. DOI: 10.1007/s12561-01909233-7.

33.Fay M.P., Proschan M.A. Wilcoxon-Mann-Whitney or T-test? On assumptions for hypothesis tests and multiple interpretations of decision rules. Stat. Surv., 2010, vol. 4, pp. 1-39. DOI: 10.1214/09-SS051.

34.Kouitcheu R., Landry D., Adonis N'da H., Moussa D., Anthony M., Lucas T., Pierre-Hugues R. Surgical Management of Lumbar and 
Thoracolumbar Spinal Fractures: Indications, Surgical Technique and Evaluation on a Series of 64 Patients Treated with Percutaneous Posterior Osteosynthesis Combined with Kyphoplasty or Anterior Arthrodesis. Open J. Modern Neurosurg., 2018, vol. 8, no. 1, pp. 84100. DOI: 10.4236/ojmn.2018.81007.

35.Bersnev V.P., Dragun V.M., Shakurov A.L. Khirurgicheskoe lechenie povrezhdenii grudopoiasnichnogo otdela pozvonochnika [Surgical treatment of the thoracolumbar spine injuries]. Rossiiskii Neirokhirurgicheskii Zhurnal im. prof. A.L. Polenova, 2013, vol. 5, no. 4, pp. 6-12. (in Russian)

36.Verheyden A.P., Spiegl U.J., Ekkerlein H., Gercek E., Hauck S., Josten C., Kandziora F., Katscher S., Kobbe P., Knop C., Lehmann W., Meffert R.H., Müller C.W., Partenheimer A., Schinkel C., Schleicher P., Scholz M., Ulrich C., Hoelzl A. Treatment of fractures of the thoracolumbar spine: recommendations of the spine section of the German Society for Orthopaedics and Trauma (DGOU). Global Spine J., 2018, vol. 8, no. 2 Suppl., pp. 34S-45S. DOI: 10.1177/2192568218771668.

37.Spiegl U.J., Jarvers J.S., Glasmacher S., Heyde C.E., Josten C. Freigabe von Bewegungssegmenten nach dorsaler Stabilisierung : Auswirkung auf die betroffenen Bandscheiben [Release of moveable segments after dorsal stabilization: Impact on affected discs]. Unfallchirurg, 2016, vol. 119, no. 9, pp. 747-754. (in German) DOI: 10.1007/s00113-014-2675-3.

38.Xue Q., Li H., Zou X., Dalstra M., Lind M., Christensen F.B., Bünger C. Alendronate treatment improves bone-pedicle screw interface fixation in posterior lateral spine fusion: an experimental study in a porcine model. Int. Orthop., 2010, vol. 34, no. 3, pp. 447-451. DOI: 10.1007/s00264-009-0759-4.

39. Saad M., El Sebaie A., Seddik M., Akar A. Minimally invasive spinal fusion technique in patients with lumbar segmental instability. Al-Azhar Int. Med. J., 2020, vol. 1, no. 9, pp. 196-201. DOI: 10.21608/AIMJ.2020.37869.1289.

40.Ghodasara N., Yi P.H., Clark K., Fishman E.K., Farshad M., Fritz J. Postoperative Spinal CT: What the Radiologist Needs to Know. Radiographics, 2019, vol. 39, no. 6, pp. 1840-1861. DOI: 10.1148/rg.2019190050.

41.Toth J.M., Wang M., Patel C.K., Arora A. Early term effects of rhBMP-2 on pedicle screw fixation in a sheep model: histomorphometric and biomechanical analyses. J. Spine Surg., 2018, vol. 4, no. 3, pp. 534-545. DOI: 10.21037/jss.2018.06.19.

42.Berkes M., Obremskey W.T., Scannell B., Ellington J.K., Hymes R.A., Bosse M.; Southeast Fracture Consortium. Maintenance of hardware after early postoperative infection following fracture internal fixation. J. Bone Joint Surg. Am., 2010, vol. 92, no. 4, pp. 823828. DOI: 10.2106/JBJS.I.00470.

The article was submitted 26.05.2021; approved after reviewing 22.09.2021; accepted for publication 19.10.2021.

\section{Information about the author:}

Olga V. Berdiugina - Doctor of Biological Sciences. 